\title{
Estimation of (co)variance components and genetic parameters for weights of red-winged tinamou using random regression models ${ }^{1}$
}

\author{
Patricia Tholon², Sandra Aidar de Queiroz ${ }^{3}$
}

\author{
1 Pesquisa financiada pelo CNPq e FAPESP. \\ 2 UFERSA - DCAN - BR 110 - Km 47, 59625-900, Mossoró - RN. \\ 3 UNESP/FCAV - Via de Acesso Prof. Paulo Donato Catellane, s/n, 14884-900, Jaboticabal, SP. Bolsita do CNPq.
}

\begin{abstract}
The objective of this work was to determine genetic parameters for body weight of tinamou in captivity. It was used random regression models in analyses of data by considering the direct additive genetic (DA) and permanent environmental effects of the animal (PE) as random effects. Residual variances were modeled by using a fifth-order variance function. The mean population growth curve was fitted by sixth-order Legendre orthogonal polynomials. Direct additive genetic effects and animal environmental permanent effect were modeled by using Legendre polynomials of order two to nine. The best results were obtained by models with orders of fit of 6 for direct additive genetic effect and of order 3 for permanent effect by Akaike information criterion and of order 3 for both additive genetic effect and permanent effect by Schwarz Bayesian information criterion and likelihood ratio test. Heritability estimates ranged from 0.02 to 0.57 . The first eigenvalue explained $94 \%$ and $90 \%$ of the variation from additive direct and permant environmental effects, respectively. Selection of tinamou for body weight is more effective after 112 days of age.
\end{abstract}

Key Words: genetic correlation, heritability, Legendre polynomials, tinamou, wild bird

\section{Estimação de componentes de covariância e de parâmetros genéticos de pesos de perdizes utilizando-se modelos de regressão aleatória}

\begin{abstract}
RESUMO - Com este trabalho objetivou-se determinar parâmetros genéticos para peso corporal de perdizes em cativeiro. Foram utilizados modelos de regressão aleatória na análise dos dados considerando os efeitos genéticos aditivos diretos (AD) e de ambiente permanente de animal (AP) como aleatórios. As variâncias residuais foram modeladas utilizando-se funções de variância de ordem 5. A curva média da população foi ajustada por polinômios ortogonais de Legendre de ordem 6 . Os efeitos genéticos aditivos diretos e de ambiente permanente de animal foram modelados utilizando-se polinômios de Legendre de segunda a nona ordem. Os melhores resultados foram obtidos pelos modelos de ordem 6 de ajuste para os efeitos genéticos aditivos diretos e de ordem 3 para os de ambiente permanente pelo Critério de Informação de Akaike e ordem 3 para ambos os efeitos pelos Critério de Informação Bayesiano de Schwartz e Teste de Razão de Verossimilhança. As herdabilidades estimadas variaram de 0,02 a 0,57 . O primeiro autovalor respondeu por 94 e $90 \%$ da variação decorrente de efeitos aditivos diretos e de ambiente permanente, respectivamente. A seleção de perdizes para peso corporal é mais efetiva a partir de 112 dias de idade.
\end{abstract}

Palavras-chave: ave silvestre, correlação genética, herdabilidade, polinômios de Legendre, tinamídeo

\section{Introduction}

The red-winged tinamou, Rhynchotus rufescens (Temmink, 1815), belongs to the order Tinamiforme, family Tinamidae, and it is a native bird from South America. The bird shows a wide geographic distribution and occurs in Argentina, Bolivia, Brazil, Paraguay, Peru, and Uruguay. Its habitats are pastures and plantations (Sick, 1985).

Both national and international exotic meat consumption are growing. So, studies on the viability of the commercial production of the tinamous, Nothoprocta perdicaria, for meat consumption have been conducted in Canada (Aggrrey et al., 1992) and Chile (Kermode, 1997). In addition, studies investigating the genetic improvement of guinea fowl and quails aiming at meat production have been carried out in France (Sauver \& Plouzeau, 1993). In Brazil, Queiroz \& Tholon (2003) have investigated the domestication and selection of the red-winged tinamou (Rhynchotus rufescens).

Some biological and productive aspects of the redwinged tinamou are already known. Using nonlinear functions to describe the growth of this bird, Tholon \& Queiroz (2007) obtained estimates of mature weight, 
expressed as asymptotic weight, of 648.2 and $806.4 \mathrm{~g}$ when logistic and Brody models were applied, respectively.

However, growth can be represented by a set of points at different ages. In this respect, random regression models take into consideration the shape of the curve of the trait studied and permit to fit random curves to each individual, with these curves being expressed as the deviation from a mean curve of the population or group of individuals (Schaeffer, 2000). In these models, random effects are modeled using continuous functions that generally consist of orthogonal and normalized Legendre polynomials, resulting in better convergence and accuracy of the results (Kirkpatrick et al., 1990).

According to Kirkpatrick \& Heckman (1989), the matrix of coefficients of the covariance function can be used to analyze patterns of inheritance. This matrix permits to calculate the eigenvalues and eigenfunctions of these functions. Thus, the trajectories described by the eigenfunctions can be used to determine the ages at which selection would be more effective (Sakaguti et al., 2003) and represent the directions in which the mean trajectory can be conducted (Albuquerque, 2004).

The objective of the present study was to estimate covariance components and genetic parameters for weights of red-winged tinamou reared in captivity using random regression models.

\section{Material and Methods}

A total of 7,369 records of weight from birth to 210 days of age of 408 birds originating from four reproduction cycles (from September to May, 2000 to 2004) were used (Table 1). The animals were reared at the Setor de Animais Silvestres, Departamento de Zootecnia, Faculdade de Ciências Agrárias e Veterinárias, UNESP, Campus de Jaboticabal.

The birds used for breeding were housed throughout the month of July in groups of two, three, four, five, and six animals. Housing was done during this period because the reproductive cycle started in August and the composition of the families varied according to the availability of animals for breeding before the beginning of the cycle. Not all females entered the laying stage during the reproductive cycles. The animals were housed as described above because of the difficulty in detecting which females had started the laying stage and to reduce the stress caused by excessive handling of birds during the reproductive cycle. The complete pedigree of part of the animals could only be established during the last two cycles.
Eggs were collected and incubated daily. At birth, the chicks were weighed, ringed and received heating during the first weeks of life due to temperature variations in the region, especially during the period from April to August. The weight of the animals was measured weekly on a Filizola digital balance with decimal precision.

The weights were modeled by random regression using a simple animal model as proposed by Meyer (1998a):

$Y_{i j}=F+\sum_{m=0}^{k_{b}-1} \beta_{m} \phi_{m}\left(t_{i j}\right)+\sum_{m=0}^{k_{A}-1} \alpha_{i m} \phi_{m}\left(t_{i j}\right)+\sum_{m=0}^{k_{R}-1} \gamma_{i m} \phi_{m}\left(t_{i j}\right)+\varepsilon_{i j}$,

in which $Y_{i j}=$ record $j$ of animal $i ; F=$ set of fixed effects including the contemporary group (year and two-week interval of birth) and sex; $\beta_{m}=m^{\text {th }}$ fixed regression coefficient of weight on age for the mean of the population; $\alpha_{i m}$ and $\gamma_{i m}=m^{\text {th }}$ direct additive genetic and permanent environmental random regression coefficients for animal $i$; $k_{b}, k_{A}$ and $k_{R}=$ orders of fit of the polynomials; $t_{i j}=j^{\text {th }}$ age of animal $i ; \phi_{m}\left(t_{i j}\right)=m^{\text {th }}$ polynomial function to be evaluated for $t_{i j} ; \varepsilon_{i j}=$ random error associated with each record $i$ of animal $j$.

The general linear model can be described as follows: $\mathrm{Y}=\mathrm{Xb}+\mathrm{Z} \alpha+\mathrm{W} \gamma+\varepsilon$,

where $Y=$ vector of observations; $b=$ vector of fixed effects that include the solutions for contemporary group and animal sex; $\alpha$ and $\gamma=$ vectors of solutions for direct additive genetic and permanent environmental random regression coefficients, respectively; $\varepsilon=$ vector of residual effects; $X, Z$, and $W=$ incidence matrices for fixed effects, direct additive genetic random effects and permanent environmental random effects of the animal, respectively.

The assumptions in relation to the components were:

$$
E\left[\begin{array}{c}
\mathrm{Y} \\
\alpha \\
\gamma \\
\varepsilon
\end{array}\right]=\left[\begin{array}{c}
\mathrm{Xb} \\
0 \\
0 \\
0
\end{array}\right] \quad \mathrm{V}\left[\begin{array}{c}
\alpha \\
\gamma \\
\varepsilon
\end{array}\right]=\left[\begin{array}{ccc}
\mathrm{K}_{\mathrm{A}} \otimes \mathrm{A} & 0 & 0 \\
0 & \mathrm{~K}_{\mathrm{R}} \otimes \mathrm{I} & 0 \\
0 & 0 & \sigma_{\varepsilon}^{2} \mathrm{D}
\end{array}\right],
$$

in which $K_{\mathrm{A}}$ and $K_{\mathrm{R}}=$ covariance matrices between direct additive genetic and permanent environmental random regression coefficients, respectively, assuming the absence of a correlation between random regression coefficients for these effects; $A=$ relationship matrix; $I=$ identity matrix; $\otimes=$ Kronecker product between matrices; $D=$ diagonal block matrix containing residual variances, and $\sigma_{\varepsilon}^{2}=$ error variance.

The formation and editing of the data files and preliminary statistical analyses were performed by using the SAS 9.1 program (2004). Birds with fewer than five records per sire and fewer than three weight records were 
excluded in order to guarantee that the first records corresponded to observations of healthy animals, because sick animals, which more frequently died during the first month of life, presented much lower weights than the mean of the population at the same stage of development. The pedigree contained 67 sires, 17 dams, and 27 grandparents.

The (co)variance components and genetic parameters were estimated by the restricted maximum likelihood (REML) method using a derivative-free algorithm available in the DFREML/DXMRR programs (Meyer, 1998b).

The covariance functions were modeled by orthogonal Legendre polynomials $\left(f_{k}\right)$ (Kirkpatrick et al., 1990) defined as:

$\phi_{k}\left(a_{i}^{*}\right)=\frac{1}{2} \sqrt{\frac{2 k+1}{2} \sum_{m=0}^{[k / 2]}(-1)^{m}\left(\begin{array}{c}k \\ m\end{array}\right)\left(\begin{array}{c}2 k-2 m \\ k\end{array}\right)\left(a_{i}^{*}\right)^{k-2 m}}$,

in which $a_{i}^{*}=$ standard age range for which the polynomial is defined $[-1$ to +1$]$.

Ages were standardized by: $a_{i}^{*}=\frac{2\left(a_{i}-a_{\min }\right)}{a_{\max }-a_{\min }}-1$, in which $a_{\min }$ and $a_{\max }$ are the minimal and maximal age, respectively, in the data set, i.e., from 1 to 210 days of age (Meyer, 1998a).

The use of continuous functions permits the effective modeling of residual variance, resulting in more parsimonious models (Meyer, 2000). The residual variances obtained by using variance functions were estimated based on their regression coefficients represented by the formula:

$\sigma_{e_{i}}^{2}=\sigma_{e_{0}}^{2}\left(1+\sum_{r=1}^{q} \beta_{r} t_{i j}^{r}\right)$,

where $\sigma_{\mathrm{e}_{0}}^{2}=$ variance of the intercept; $\beta_{r}=$ regression coefficients $r$ of the variance functions of order $q ; t_{i j}=$ ages $i$ of each animal $j$.

The order of fit for fixed effects was 6 since there was only a small difference in the mean square value of residual variance when compared to the other models, which were tested until an order of 9. An order of fit of 6 for fixed effects was chosen to avoid overparameterization of the models. After determination of the best order of fit for fixed effects, genetic analysis was first performed using a homogenous residual variance structure.

Next, heterogeneity of residual variances was assumed by considering 210 classes of age (CL210), weekly classes (CL30), and residual variance functions. The best estimates were obtained with fifth-order variance functions (FV5), and the orders of fit for genetic and permanent environmental effects were then tested. The order of the polynomial was reduced according to the variance estimates of the random regression coefficients and the associated eigenvalues.
Table 1 - Data structure used in the random regression analyses

\begin{tabular}{cc}
\hline Number of records & Number of animals \\
\hline 3 & 4 \\
13 & 5 \\
11 & 6 \\
7 & 7 \\
10 & 8 \\
3 & 9 \\
2 & 10 \\
4 & 11 \\
10 & 12 \\
13 & 13 \\
18 & 14 \\
26 & 15 \\
8 & 16 \\
19 & 17 \\
26 & 18 \\
62 & 19 \\
22 & 20 \\
20 & 21 \\
25 & 22 \\
34 & 23 \\
28 & 24 \\
32 & 25 \\
10 & 26 \\
2 & 27 \\
\hline
\end{tabular}

The criteria used for the determination of the best fitting model were the likelihood ratio test (LRT), Akaike's information criterion (AIC), and Schwarz Bayesian information criterion (BIC). The last two criteria are given by: $A I C=-2 \log L+2 p$ and BIC $=-2 \log L+\log (N-r(X))$ (Wolfinger, 1993), in which $p=$ number of parameters estimated; $N=$ number of data; $r(X)=$ rank of the incidence matrix of fixed effects in the model; $\log L=\log$ arithm of the restricted maximum likelihood function.

The LRT should only be applied when the models are nested, i.e., when the most complex model (larger number of parameters) is derived from a less parameterized model by the addition of at least one parameter. The test will determine whether these additional parameters significantly improve the model. Defining L0 as the simplest model (smallest number of parameters) and L1 as the most complex model (largest number of parameters), the hypothesis to be tested is that the two models are equivalent $\left(H_{0}\right)$. The LRT statistics $(-2[\ln \mathrm{L} 1-\ln \mathrm{L} 0])$ follows a chi-squared distribution in which the degrees of freedom are given by the difference in the number of parameters among models. $H_{0}$ is rejected if the value of the test is higher than the critical value at the level of significance.

Models using different orders of fit (from 2 to 9 ) for genetic and permanent environmental effects were tested (Table 2). 
Table 2 - Number of parameters (p), logarithm of the maximum likelihood function (log L), Akaike's information criterion (AIC), Schwarz Bayesian information criterion, and likelihood ratio test (LRT) obtained for the models

\begin{tabular}{|c|c|c|c|c|c|c|}
\hline Model & $\mathrm{p}$ & $\log L$ & AIC & BIC & \multicolumn{2}{|c|}{ LRT } \\
\hline G633FV5 & 18 & -4123.313313 & 48182.626626 & 48306.917297 & & - \\
\hline G643FV5 & 22 & -4596.672076 & 49237.344152 & 49389.254973 & $(2-1)$ & $473.359 * *$ \\
\hline G653FV5 & 37 & -24747.038110 & 49548.076221 & 49734.512228 & $(3-2)$ & $150.366 * *$ \\
\hline G654FV5 & 31 & -25414.942185 & 50891.884257 & 51105.940413 & $(4-3)$ & $667.904 * *$ \\
\hline G655FV5 & 36 & -24786.315891 & 49644.631781 & 49893.213123 & $(5-4)$ & $628.626 * *$ \\
\hline G656FV5 & 42 & -24917.941680 & 49919.883361 & 50209.894927 & $(6-5)$ & $231.626 * *$ \\
\hline G663FV5 & 33 & -24152.162494 & 48170.324989 & 48398.191220 & $(7-6)$ & $865.779 * *$ \\
\hline G664FV5 & 37 & -24726.019353 & 49526.038707 & 49781.525087 & $(8-7)$ & $673.857 * *$ \\
\hline G665FV5 & 42 & -24959.164052 & 50002.328105 & 50292.339671 & $(9-8)$ & $233.145 * *$ \\
\hline G666FV5 & 48 & -24196.543818 & 48489.087637 & 48820.529427 & $(10-9)$ & $762.620 * *$ \\
\hline
\end{tabular}

FV5 = fifth-order variance function; G_6_5_3_FV5 = order of fit of 6 for mean effect of the population, of 5 for additive genetic effects, and of 3 for permanen environmental effects, respectively. ${ }^{* *}(\mathrm{P}<0.01)$.

\section{Results and Discussion}

The highest concentration of records was observed from the $4^{\text {th }}$ to the $12^{\text {th }}$ week of age (Figure 1 ). Mean weights increased with age, showing a cubic tendency $\left(R^{2}=0.9954\right)$, with values ranging from $38.9 \mathrm{~g}$ at birth to $667.39 \mathrm{~g}$ at 210 days of age (Figure 1). Standard deviations increased gradually until week 8 and tended to be stable until week 30 . The coefficients of variation only presented small oscillations during the period studied, with a minimum value of $13.1 \%$ in the first week of life (from 1 to 7 days of age) and a maximum value of $20.9 \%$ in the 8 th week (from 56 to 63 days of age).

The AIC value indicated the model with orders of fit of 6 for direct genetic effects and of 3 for permanent environmental effects (G663FV5) to be the best model (Table 2). According to the LRT and BIC values, the model with orders of fit of 3 for direct genetic effects and permanent environmental effects of the animal (G633FV5) was the most adequate. This model was more parsimonious and reduced the time necessary to reach convergence of the analyses and computational requirements.

Additive genetic and permanent environmental effects of the animal presented the highest variance estimates associated with the intercept. The correlation between the intercept and the linear coefficient of the additive genetic effect was positive and high (Table 3), and between the intercept and quadratic coefficient it was positive and moderate, however. For permanent environmental effects, the correlation between the intercept and linear coefficient was high and positive, and the correlations between the linear and quadratic coefficients and the intercept were both negative (Table 3).

There was a progressive increase in standard deviations (Figure 2) and, consequently, in genetic and phenotypic variances, probably because of the smaller number of weight records at subsequent ages and greater individual differences between animals.

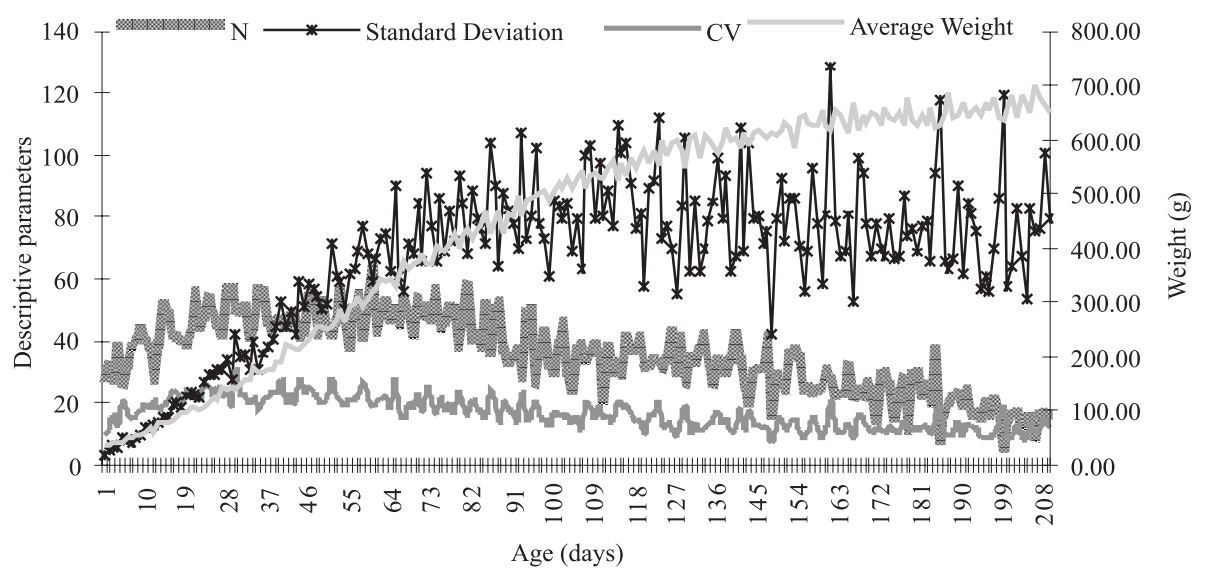

Figure 1 - Distribution of the number of records (N), mean weight (g), standard deviation (g), and coefficient of variation (CV) (\%) as a function of age of red-winged tinamou. 
Table 3 - Estimates of variances (on the diagonal), covariances (below the diagonal) and correlations (above the diagonal) between the random regression coefficients of the matrix of coefficients and their eigenvalues $(\lambda)$ for the random effects of the animal

\begin{tabular}{|c|c|c|c|c|c|}
\hline & & Intercept & Linear coefficient & Quadratic coefficient & $\lambda$ \\
\hline \multirow[t]{3}{*}{ Additive genetic } & 1 & 2733.520 & 0.919 & 0.413 & 4271.82 \\
\hline & 2 & 1960.780 & 1664.900 & 0.738 & 259.125 \\
\hline & 3 & 248.871 & 346.954 & 132.670 & 0.140 \\
\hline \multirow[t]{3}{*}{ Permanent environmental } & 1 & 5379.560 & 0.706 & -0.805 & 6229.220 \\
\hline & 2 & 1578.930 & 929.709 & -0.148 & 666.603 \\
\hline & 3 & -1429.920 & -109.460 & 586.661 & 0.110 \\
\hline
\end{tabular}
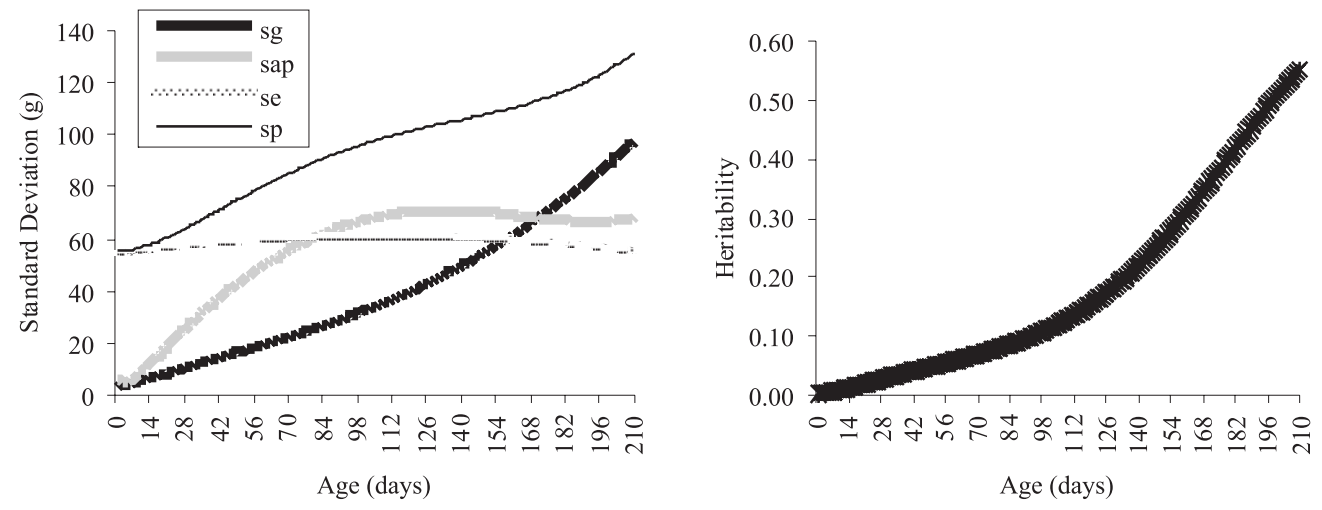

Figure 2 - Estimates of direct genetic (sg), permanent environmental (sap), residual (se) and phenotypic (sp) standard deviations and heritability obtained by using model G633FV5.

Permanent environmental variance increased substantially until 17 weeks of age (119 days), a period coinciding with the onset of puberty of the animals. The heritability estimates showed the same trend as additive genetic variances, with higher estimates being observed after 14 weeks of age (98 days).

An increase in heritabilities during late stages of animal development was also reported by Dionelo et al. (2008) who studied Japanese quail until 42 weeks of age, and by Akbaş et al. (2004) for quail until 6 weeks of age. These authors considered residual variances to be homogeneous. However, Saatci et al. (2006), when studying Japanese quail until 42 weeks of age, estimated heritabilities of low magnitude that showed little variation ( 0.13 to 0.19$)$. In general, difficulties are found when estimating genetic parameters when the animals reach maturity and the authors suggested that the estimates could be overestimated.

The genetic, permanent environmental and phenotypic correlations between adjacent ages were high and positive and decreased in magnitude with increasing interval between ages (Figure 3). Negative genetic correlations were observed after 90 days of age. At older ages (week 18), the correlations between weights remained stable, with little variation between adjacent weight classes, indicating that the set of genes encoding weight after sexual maturity are the same as for weight at 210 days of age. Greater oscillations in the correlations, and consequently greater instabilities, were observed during the first weeks of life of the birds, a finding indicating larger genetic differences between these stages or even inadequate model fit due to the lack of inclusion of maternal effects.

The correlations between permanent environmental effects of the animals presented greater oscillations at older ages (after 140 days), finding demonstrating differences between sexes present after sexual maturity of the birds.

The eigenvalues for additive genetic effects were lower than those for permanent environmental effects of the animal (Table 4). Both effects showed greater variation in the first (linear) eigenvalue, indicating that this eingenvalue is the best possibility to alter the growth curve by selection.

The first eigenfunction (Figure 4) indicated increasing weight gains after the second week of life (14 days of age) and no variation in the first two weeks. This eigenfunction explained $94.28 \%$ of the genetic variation. The second eigenfunction indicated a reduction of weight until 112 days of age and an increase at subsequent ages, explaining approximately $5.72 \%$ of the genetic variation. The third eigenfunction showed similar trend to that of the second eigenfunction, but weight reduction would only occur until 70 days of age. This eigenfunction explained little or none of the genetic variation. 
A similar tendency has been reported by Akbaş et al. (2004) for Japanese quail and by Pelicioni et al. (2009) for beef cattle. The authors observed that the first eigenfunction was responsible for most of the genetic variation.

Eigenfunctions are continuous functions whose coefficients are formed by the elements of the eigenvalues of the matrices of coefficients of the covariance functions. There is an eigenvalue for each eigenfunction that corresponds to the proportion of total variance explained by the eigenfunction (Sakaguti et al., 2003), providing the amount of variation in the population that corresponds to the relative eigenfunction (Albuquerque, 2004). According to Van der Werf (2001), the sign of the eigenfunctions is not important for their interpretation but rather the trajectory that the values assume during the growth of the animal, indicating probable directions of selection, and the magnitude of the eigenvalue associated with each respective eigenfunction.

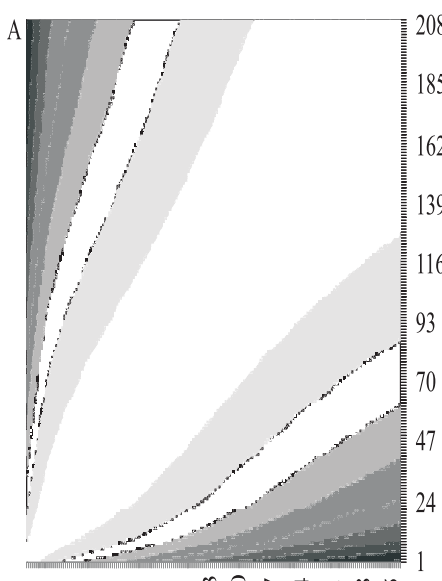

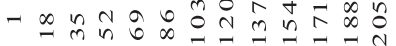
Age (days)

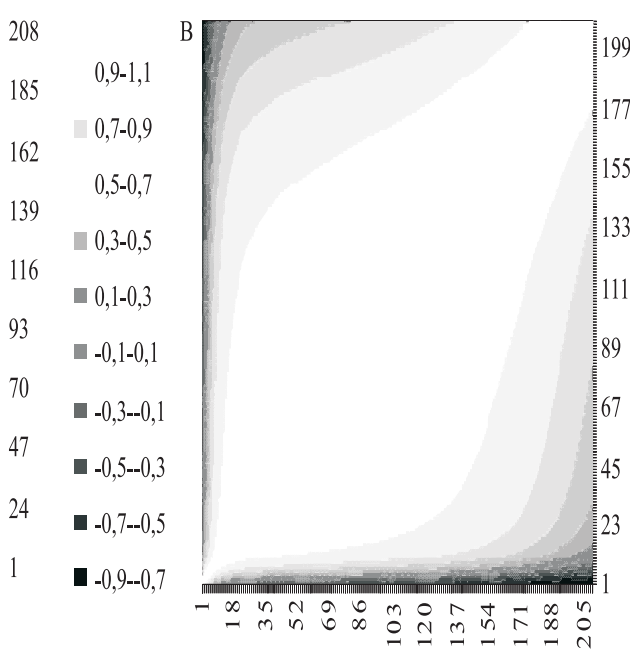

Age (days)

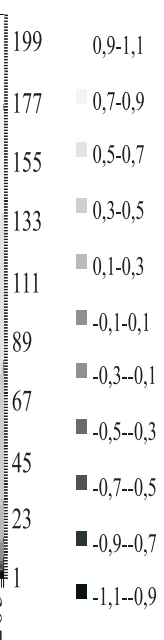

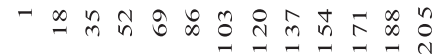

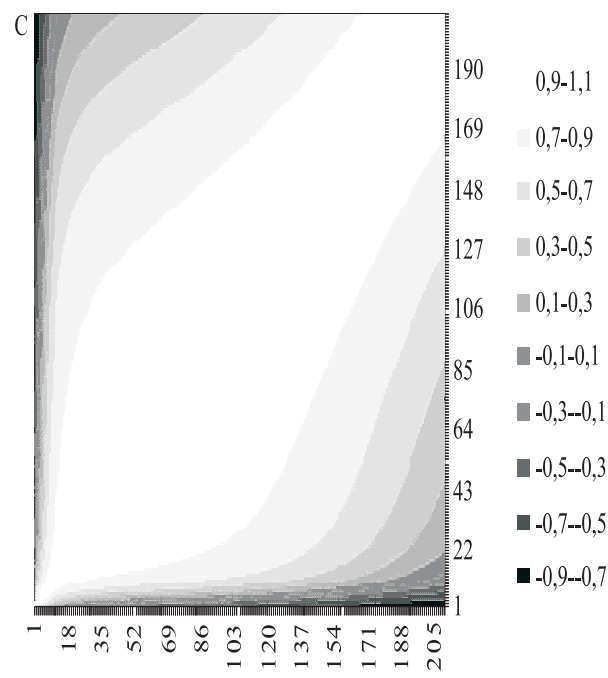

Age (days)

Figure 3 - Estimates of direct genetic (a), permanent environmental (b) and phenotypic (c) correlations for body weight of red-winged tinamou obtained with model G633FV5.

Table 4 - Eigenvalues $(\lambda)$ for additive genetic and permanent environmental effects

\begin{tabular}{lccc}
\hline & Intercept & Linear coefficient & Quadratic coefficient \\
\hline$\lambda$ Additive genetic & 4271.820 & 259.125 & 0.140 \\
$\%$ & 94.2781 & 5.7188 & 0.003 \\
$\lambda$ Permanent environmental & 6229.220 & 666.603 & 0.110 \\
$\%$ & 90.3318 & 9.6667 & 0.0001 \\
\hline
\end{tabular}

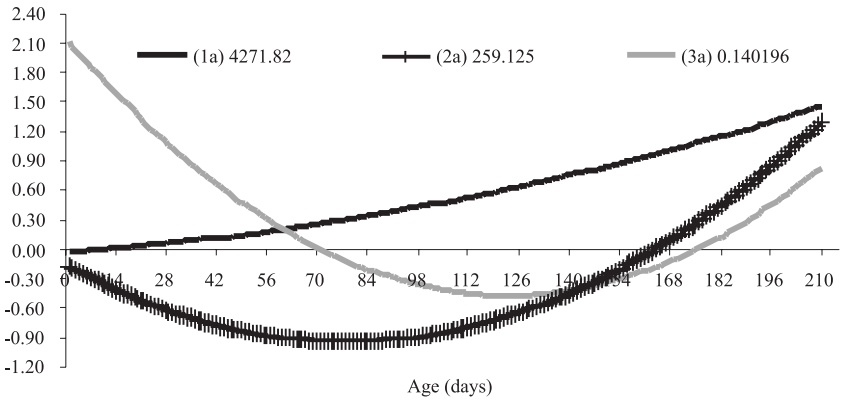

Figure 4 - Eigenfunctions and eigenvalues for additive genetic effects of body weight in red-winged tinamou estimated by using model G633FV5.

\section{Conclusions}

Random regression models are adequate to describe variations in the growth of the red-winged tinamou over time. Among the studied models, G633FV5 shows the best fit. Identification of individuals with better body weight performance is more effective after 112 days of age, a period when the expression of additive variance and heritabilities indicate that selection will result in effective gains. The genetic correlations among weights after 18 weeks of age indicate lower genetic variability when compared to the first weeks and lower correlated 
responses are therefore expected. Selection for shape of the growth curve is possible, with the first eigenfunction explaining most of the variation, in addition to permitting positive gains throughout the growth period of the animals.

\section{References}

AGGREY, S.E.; NICHOLS, C.R.; CHENG, M. The partridge tinamou for commercial meat production: A preliminary evaluation. In: WORLD'S POULTRY CONGRESS, 19., 1992, Amsterdam. Anais... Amsterdam, 1992. v.1, p.360.

AKBAŞ, Y.; TAKMA, Ç.; YAYLAK, E. Genetic parameters for quail body weights using a random regression model. South African Journal of Animal Science, v.34, n.2, p.104-109, 2004.

ALBUQUERQUE, L.G. Regressão aleatória: nova tecnologia pode melhorar a qualidade das avaliações genéticas. In: SIMPÓSIO DA SOCIEDADE BRASILEIRA DE MELHORAMENTO ANIMAL, 5., 2004, Pirassununga. Anais... Pirassununga: Sociedade Brasileira de Melhoramento Animal, [2004]. (CD-ROM).

DIONELLO, N.J.L.; CORREA, G.S.S.; SILVA M.A. et al. Estimativas da trajetória genética do crescimento de codornas de corte utilizando modelos de regressão aleatória. Arquivo Brasileiro de Medicina Veterinária e Zootecnia, v.60, n.2, p.454-460, 2008.

KERMODE, D. The production of non-traditional poultry in British Columbia and the introduction of a new poultry species: Partridge Tinamou. 1997. 183f. Thesis (Master in Animal Science) - University of British Columbia, 1997. Available at: <https://circle.ubc.ca/bitstream/handle/2429/5960/ ubc_1997-0249.pdf > Accessed: 18/4/2010.

KIRKPATRICK, M.; HECKMAN, N.A. Quantitative genetic model for growth, shape and other infinite-dimensional characters. Journal of Mathematical Biology, v.27, p.429-450, 1989.

KIRKPATRICK, M.; LOFSVOLD, D.; BULMER, M. Analysis of the inheritance, selection and evolution of growth trajectories. Genetics, v.124, p.979-993, 1990.

MEYER, K. Estimating covariance functions for longitudinal data using a random regression model. Genetic Selection Evolution, v.30 p.221-240, 1998a.
MEYER, K. "DXMRR” - A program to estimate covariance functions for longitudinal data by restricted maximum likelihood. In: WORLD CONGRESS ON GENETICS APPLIED TO LIVESTOCK PRODUCTION, 6., 1998, Armidale, Australia. Anais... Armidale, 1998b. v.27, p.465-466.

MEYER, K. Random regressions to model phenotypic variation in monthly weights of Australian beef cows. Livestock Productions Science, v.65, p.19-38, 2000.

PELICIONI, L.C.; ALBUQUERQUE, L.G.; QUEIROZ, S.A. Estimação de componentes de co-variância para pesos corporais do nascimento aos 365 dias de idade de bovinos Guzerá empregando-se modelos de regressão aleatória. Revista Brasileira de Zootecnia, v.38, n.1, p.50-60, 2009.

QUEIROZ, S.A.; THOLON, P. Criação de perdizes em cativeiro - a experiência do departamento de zootecnia da FCAV - UNESP. In: QUEIROZ, S.A. (Org.). I Simpósio de produção de perdizes (Rhynchotus rufescens) em cativeiro. ed. Saquei: Jaboticabal, 2003. p.1-17.

SAATCI, M.; DEWI, I.A.; AKSOY, A.R. Application of REML procedure to estimate the genetic parameters of weekly liveweights in one-to-one sire and dam pedigree recorded Japanese quail. Journal of Animal Breeding and Genetics, v.120, n.1, p.23-28, 2003.

SAKAGUTI, E.S.; SILVA, M.A.; QUAAS, R.L. et al. Avaliação do crescimento de bovinos jovens da raça Tabapuã, por meio de análises de funções de covariâncias. Revista Brasileira de Zootecnia, v.32, n.4, p.864-874, 2003.

SAUVER, B.; PLOUZEAU, M. Technical and economical aspects of guinea fowl production in the world. Nouzilly, France: Station de Recherches Avicoles, INRA, 1993. p.319-323.

SCHAEFFER, L.R. [2000]. Random regression models. Available at: <http://www.aps.uoguelph.ca/ lrs/ABModels/NOTES/RRM14a .pdf> Accessed: 15/4/2010.

SICK, H. Ornitologia brasileira, uma introdução. Brasília: Universidade de Brasília, 1985. v.1, 482p.

STATISTICS ANALYSIS SYSTEMS - SAS. User's guide: Version 9.1, Cary, 2004. p.5136.

THOLON, P.; QUEIROZ, S.A. Models for the analysis of growth curves for rearing tinamous (Rhynchotus rufescens) in captivity. Revista Brasileira de Ciência Avícola, v.9, n.1, p.23-31, 2007.

VAN der WERF, J. Random regression in animal breeding. Jaboticabal: Universidade Estadual Paulista, 2001. 50p. (notas de curso)

WOLFINGER, R.D. Covariance structure in general mixed models. Communication in Statistics, v.22B, p.1079-1106, 1993. 